\title{
GROWTH AND PRODUCTIVITY AS INFLUENCED BY NUTRIENT MANAGEMENT PRACTICES ON PIGEON PEA [Cajanus cajan (L.) Millsp.] IN UPLAND ALFISOLS OF TRIPURA
}

\author{
S. Ray, Biman De* and S. Hazari \\ All India Co-ordinated Research Project on Pigeon Pea, College of Agriculture, Lembucherra \\ West Tripura, Tripura-799210, India
}

\begin{abstract}
Pigeon pea [Cajanus cajan (L.) Millsp.] is the rich sources of dietary protein, carbohydrate \& certain minerals but its poor yield needs to formulate a nutrient management practices for higher productivity in upland alfisols of Tripura and to combat it, an experiment was conducted during three consecutive kharif seasons at College of Agriculture, Lembucherra, Tripura comprising of two levels of Lime (150 and $200 \mathrm{~kg}$ $\left.\mathrm{ha}^{-1}\right)$ in main plot and two levels of molybdenum seed treatment $(0$ and $4 \mathrm{~g} \mathrm{~kg}^{-1}$ of seed) in sub plot and 4 levels of recommended doses, viz., $0 \%$ of RDF ha ${ }^{-1}, 50 \%$ of RDF ha ${ }^{-1}, 75 \%$ of RDF ha ${ }^{-1}$ and $100 \%$ of RDF ha ${ }^{-1}$ (Recommended dose @ 20:60:40 of NPK). It was revealed that by the use of $100 \%$ RDF ha ${ }^{-1}$ with $150 \mathrm{~kg} \mathrm{ha}^{-1}$ lime and $4 \mathrm{~g} \mathrm{~kg}^{-1}$ of molybdenum seed treatment leads to higher yield and return per rupee respectively. But by the use of $100 \%$ RDF ha ${ }^{-1}$ with $200 \mathrm{~kg} \mathrm{ha}^{-1}$ lime and $4 \mathrm{~g} \mathrm{~kg}^{-1}$ of molybdenum seed treatment, return per rupee was recorded at 2.98. The investigation reflects that by the use of $75 \% \mathrm{RDF}^{-1}$ return per rupee (3.78) was less compared to $100 \% \mathrm{RDF} \mathrm{ha}^{-1}$ but significant with saving the cost of $25 \%$ RDF ha ${ }^{-1}$ and soil health from the excessive use of fertilizer for sustaining the agricultural growth.
\end{abstract}

Keywords: Pigeon pea, Lime, Molybdenum, Stick yield, Test weight, Harvest index, Economics

\section{INTRODUCTION}

Pigeonpea [Cajanus cajan (L.) Millsp.] is the most versatile food legume with diversified uses as food, feed, fodder and fuel. It accounts for 5\% of global pulse production. Of the global acreage and production, Asia is nearly the sole contributor and of that too, India alone accounts for over three-fourths of area and four-fifths of production (Ahlawat et al., 2005). Pigeonpea ranks second in both acreage (3.58

* Corresponding author email: biman_de@ rediffmail.com

Received: 01.12.2014 
million ha) and production (2.74 million tonnes) among the pulses in India with average productivity of $765 \mathrm{~kg} \mathrm{ha}^{-1}$. Pigeon pea is the rich sources of dietary protein, carbohydrate and certain minerals in the vegetarian diet in India (Gopalan et al., 1971). Besides being the major sources of dietary protein, they also plays an important role in sustaining nutrient level in soil productivity by fixing atmospheric nitrogen (Kumar Rao and Dart, 1987) for crop productivity. On the upland hill slopes, pigeon pea serves as soil conserving crop and check erosion to some extent. However, there are many factors influencing atmospheric nitrogen fixation through symbiosis. On field condition, soil moisture, temperature, soil $\mathrm{pH}$, mineral nutrient supply, salinity and nodule damage by insects are presumably the most important factors limiting the biological nitrogen fixation (Kumar Rao, 1990). As per as the productivity is concerned, pigeon pea has been observed almost stagnation throughout the state. Soil acidity and Al toxicity inhibits and restricts symbiotic nitrogen fixation and root growth respectively (Das, 1996). Again, nutrient limitations result from deficiencies of micronutrients such as molybdenum (Mo), zinc $(\mathrm{Zn})$, boron (B) and iron (Fe) affects legume production (Bhuiyan et al., 1999). Inadequate nodulation of pigeonpea can be associated with low plant available Mo. Increase in flower numbers and pod set improvement are influenced by Mo (Prasad et al., 1998). Application of recommended doses of fertilizers (RDF), the major, secondary and micronutrients, to pigeonpea is essential for higher yield under rainfed conditions. To combat the above stated low yield, an experiment was designed to find out the influence of liming and micronutrients on production of pigeonpea in Alfisols under rainfed conditions.

\section{MATERIALS AND METHODS}

A field experiment was conducted during three consecutive kharif seasons of 2011-12, 2012-13 and 2013-14 at the research farm of College of Agriculture, Lembucherra, Tripura situated between $22^{\circ} 57^{\prime} \mathrm{N}$ latitude and $91^{\circ} 09^{\prime}$ E longitude. The soil of the experimental site was sandy loam having $\mathrm{pH}$ of 5.4, organic carbon $\left(0.79 \mathrm{~g} \mathrm{~kg}^{-1}\right)$, available nitrogen of $260.0 \mathrm{~kg} \mathrm{ha}^{-1}$, available phosphorus of $19.0 \mathrm{~kg} \mathrm{ha}^{-}$ ${ }^{1}$, and available potash of $123.0 \mathrm{~kg} \mathrm{ha}^{-1}$. The experiment was carried out during the kharif seasons where the climate of hilly zone is sub-tropical in nature with distinctive characteristics of high rainfall, high humidity and a prolonged winter (Table-1). The treatments comprised two levels of Lime (150 and $\left.200 \mathrm{~kg} \mathrm{ha}^{-1}\right)$ in main plot $A$ and two levels of molybdenum seed treatment ( 0 and $4 \mathrm{~g} \mathrm{~kg}^{-1}$ of seed) in the main plot B and 4 treatments, viz., $0 \%$ of RDF ha ${ }^{-1}, 50 \%$ of RDF ha ${ }^{-1}, 75 \%$ of RDF ha ${ }^{-1}$ and 100\% of RDF ha ${ }^{-1}$ (Recommended dose @ 20:60:40 of NPK). The treatments were replicated thrice in split-split plot design. The plot size was 5.8 $\mathrm{m} \times 4.2 \mathrm{~m}$. Pigeon pea variety 'UPAS-120' was grown during mid June keeping seed rate of $15 \mathrm{~kg} \mathrm{ha}^{-1}$. Lime as per treatment was applied 21 days before sowing of pigeonpea. Molybdenum in the form of sodium molybdate was applied as seed treatment @ 4g molybdenum $\mathrm{kg}^{-1}$ of seed. The seed treatment was done in solution of 
sodium molybdate for four hours and then these seeds were treated and spread over gunny bag for two hours for leaching the solution from the seed. The crop was harvested in February in first year and January in second and third year respectively. Fertilizers were applied in the form of urea, single super phosphate and murate of potash, respectively. Half of the nitrogenous fertilizer and entire dose of $\mathrm{P}_{2} \mathrm{O}_{5}$ and $\mathrm{K}_{2} \mathrm{O}$ were applied treatment-wise at the time of land preparation and the rest half of nitrogen were top dressed at 60 days after sowing (DAS). The data collected from the field and laboratory experiments were subjected to statistical analysis appropriate to the design and the treatment variations were tested for significance by $F$ test. The economics of growth and yield of pigeon pea as influenced by the liming, molybdenum seed treatment and levels of recommended dose were calculated. Prices of the produce were taken as per the minimum support price, Rs 4350/- per quintal for pigeon pea grain and Rs. 200/- per quintal stick (alternative to fire wood) as well several persons use these sticks for making fencing hedge. On the basis of that benefit cost ratio were calculated.

\section{RESULTS AND DISCUSSION}

\section{Growth and flowering characters:}

In general, plant height increased with advancement in age of crop upto 120130 DAS. Pooled data showed that plant height and primary branches was nonsignificantly affected by liming for the three years at all the stages of plant growth. Non-significantly higher plant height was observed in case of liming @ $150 \mathrm{~kg} \mathrm{ha}^{-1}$ than liming@200 kg ha ${ }^{-1}$. The pooled data of three years showed that the plant height at harvest was $125.71 \mathrm{~cm}$ in case of liming @ $150 \mathrm{~kg} \mathrm{ha}^{-1}$ whereas $124.86 \mathrm{~cm}$ in case of liming @ $200 \mathrm{~kg} \mathrm{ha}^{-1}$, respectively (Table-2 and 3) which might be due to the reduced toxicity effect of aluminum and manganese after the application of lime whereas higher application leads to soil deficient in iron, copper and zinc with reduced availability of phosphorus and potassium. The results confirmed the findings of Das, 1996, Verma et al., 2004 and Sharma et al., 2010.

Among the molybdenum seed treatment the pooled data of three years reflects that plant height differs significantly where as primary branches differs nonsignificantly. At $\mathrm{M}_{4}$ (Molybdenum seed treatment @ $4 \mathrm{~g} \mathrm{~kg}^{-1}$ seed) plant height were $10.54 \%$ higher than $\mathrm{M}_{0}$ (without seed treatment) and in case of primary branches $\mathrm{M}_{4}$ were $8.41 \%$ non-significantly higher than $\mathrm{M}_{0}$. This increase was mainly due to molybdenum having important role in iron absorption with an essential component of major enzyme nitrate reductase in plants, carbohydrate metabolism and again a structural component of nitrogenase in all legume crops. These results are confirmed by the experiments of Verma et al., 2004 and Sharma et al., 2010.

Again, in case of different levels of substitution of recommended dose both plant height and primary branches differs significantly with the highest plant height of $139.65 \mathrm{~cm}$ in $\mathrm{R}_{100}$ (Full recommended dose @ 20: 60: 40) while primary branches 
showed higher values of $134.60 \mathrm{~cm}$ in $\mathrm{R}_{75}\left(75 \%\right.$ of $\left.\mathrm{RDF} \mathrm{ha}{ }^{-1}\right)$. From the pooled data, plant height and primary branches highest values are $139.65 \mathrm{~cm}$ and 10.72 respectively which might be due to greater availability and synchronous supply of plant nutrients throughout the growth period. $\mathrm{R}_{0}$ (untreated) attained the lowest values. Reduction in recommended dose of fertilizer beyond $75 \%$ resulted in significantly lower yields. Slow organic matter decomposition through changes in nutrient mineralization/immobilization improved the soil fertility and the potential nutrient supply to the growing cultivated crops (De and Bandyopadhyay, 2013). The results are in confirmatory of the findings by Sharma et al., 2007 and De et al., 2009.

From pooled data of three years (table 2 ) it is depicted that days to $1^{\text {st }}$ flowering and $50 \%$ flowering (days) were found to be differs non-significantly for liming, molybdenum seed treatment and different levels of recommended dose. Increase in flower numbers, pod set improvement, and reduction in days to flowering are influenced by Mo (Prasad et al., 1998).

\section{Yield attributing characters:}

The influence of liming, molybdenum seed treatment and different levels of recommended dose on no. of pods per plant, number. of seed per pod and 100 seed weight of maize was showed in the pooled data presented in the table 3. As regards liming, the mean maximum values of pods plant ${ }^{-1}$, seed pod $^{-1}$ and 100 seed weight were 113.07 and 3.54 in $\mathrm{L}_{150}$ (Liming @ $150 \mathrm{~kg} \mathrm{ha}^{-1}$ ) and $7.85 \mathrm{~g}$ in $\mathrm{L}_{200}$ (Liming @ $200 \mathrm{~kg} \mathrm{ha}^{-1}$ ) which are 6.62 and $1.14 \%$ higher than $\mathrm{L}_{200}$ and $-0.38 \%$ higher than $\mathrm{L}_{150}$ respectively. This might be due to poor effect of sesquioxides after liming. The values of number of seed $\operatorname{pod}^{-1}$ and 100 seed weight varies non-significantly indicating that lime dose from 150 to $200 \mathrm{~kg} \mathrm{ha}^{-1}$ had not reflected on the yield (Das, 1996 and Sharma et al., 2010).

There was significant difference between $\mathrm{M}_{4}$ (molybdenum seed treatment@ $4 \mathrm{~g} \mathrm{~kg}^{-1}$ ) and $\mathrm{M}_{0}$ (untreated) treatments in case of pods plant ${ }^{-1}$. From the pooled data $\mathrm{M}_{4}$ showed maximum mean values of $116.02,3.58$ and $8.10 \mathrm{~g}$ of pods plant ${ }^{-1}$, seeds $\operatorname{pod}^{-1}$ and 100 seed weight respectively. $\mathrm{M}_{4}$ treatment yielded $12.5,3.46$ and $7.00 \%$ than $\mathrm{M}_{0}$ and the reason behind it was mainly due to molybdenum having important role in plants with structural component of nitrogenase enzyme. Yield increase in these treatments may be the result of inhibition in flower and pod abscission, improvement in morpho-physiological characters in addition to higher pods per plant. Velayutham et al. (2003) and Reddy et al. (2007) confirmed the reports.

Again, in case of different levels of substitution of recommended dose both seed $\operatorname{pod}^{-1}$ and 100 seed weight differs significantly with highest in $R_{100}(100 \%$ of RDF) but pods per plant differs significantly having highest in $\mathrm{R}_{75}$ ( $75 \%$ of RDF). From the pooled data values having highest recorded are 118.73 in pods plant ${ }^{-1}, 3.75$ in seeds pod $^{-1}$ and $8.69 \mathrm{~g}$ in 100 seed weight which is due to synchronous supply of plant nutrients throughout the growth period. The lowest being recorded with $\mathrm{R}_{0}$ 
(untreated). The results are in confirmatory of the findings by De et al., 2009 and Sharma et al., 2007.

\section{Yield characters:}

As per the pooled data (Table-3) of three years, grain yield and stick yield attained non-significant values in case of liming. $\mathrm{L}_{200}$ (Liming @ of $200 \mathrm{~kg} \mathrm{ha}^{-1}$ ) being the highest value of $1519.50 \mathrm{~kg} \mathrm{ha}^{-1}$ of grain and $4008.40 \mathrm{~kg} \mathrm{ha}^{-1}$ with stick yield under $\mathrm{L}_{150}$. This might be due to increased values in pods plant ${ }^{-1}$, seeds pod ${ }^{-1}$ and 100 test weight. $\mathrm{L}_{200}$ had $1.00 \%$ and $\mathrm{L}_{150}$ by $2.51 \%$ higher than $\mathrm{L}_{150}$ and $\mathrm{L}_{200}$ in case of grain yield and stick yield respectively. Results were confirmed by the findings of De and Bandyopadhyay, 2013.

Higher values under molybdenum seed treatment also depicts the same reason of increased values under primary branches and yield attributing characters (Table-3). $\mathrm{M}_{4}$ are significantly 11.51 and $11.10 \%$ higher than $\mathrm{M}_{0}$ (untreated). The results are confirmed by the findings of Sharma et al., (2010)

Again in case of different levels of recommended dose substitution, $\mathrm{R}_{100}$ showed better yield characters than $R_{75}$ followed by $R_{50}$ and $R_{0}$. They differ significantly from $\mathrm{R}_{100}$ over $\mathrm{R}_{0}$ by 87.11 and $66.58 \%$ in case of grain yield and stick yield keeping the reason behind it the same as earlier one. Confirmations are obtained from the results of findings by Sharma et al., 2010 and De and Bandyopadhyay, 2013.

From the polynomial curve fitting (Figure 1 and 2), it showed that with the increase in fertilizer doses beyond $75 \mathrm{~kg} \mathrm{ha}^{-1}$, increase in grain yield was achieved but with decreasing rate at liming @ 150 and $200 \mathrm{~kg} \mathrm{ha}^{-1}$ with treated seeds whereas non-treated seeds showed some deviation which might be due to direct or indirect effect of molybdenum with liming.

\section{Economic Analysis:}

It was observed that by the application of lime @ $150 \mathrm{~kg} \mathrm{ha}^{-1}$, highest grain yield was obtained $20.93 \mathrm{tha}^{-1}$ with net return Rs. $82669.70 \mathrm{ha}^{-1}$ and return per rupee was 4.09 whereas by the application of more lime i.e., $200 \mathrm{~kg} \mathrm{ha}^{-1}$, highest grain yield was recorded $18.57 \mathrm{t} \mathrm{ha}^{-1}$ with net return Rs. $70093.25 \mathrm{ha}^{-1}$ due to higher cost of cultivation (Rs. 20,470.00 ha ${ }^{-1}$ ) compare to the $\mathrm{L}_{150}$ treatments and return per rupee was recorded 3.42 (Table-4). These results are confirmed with the findings of Sharma et al. (2010). Puste and Jana (1995) reported that the yield attributes and seed yield of pigeonpea varieties were significantly influenced by phosphorus and zinc application with a maximum benefit-cost ratio of 4.12 .

The findings revealed that the application of molybdenum @ $4 \mathrm{~g} \mathrm{~kg}^{-1}$ of seed as micronutrient was highly significant as compare to $\mathrm{M}_{0}$ treatments. The result showed that grain yields in $\mathrm{M}_{4}$ treatments $20.92 \mathrm{t} \mathrm{ha}^{-1}$ were followed by $19.85 \mathrm{t} \mathrm{ha}^{-1}$ and 18.57 $\mathrm{t} \mathrm{ha}^{-1}$ at $\mathrm{L}_{200}$ with per day return of Rs. 688.91, 628.52 and 584.11 respectively. Yadav et al. (1997) reported that with the application of $100 \%$ dose of recommended 
fertilizer pigeon pea gave a higher grain yield elevating both net returns and benefitcost ratio. These results corroborated the findings of Ramakrishna (2005). Thus the application of $100 \% \mathrm{RDF} \mathrm{ha} \mathrm{h}^{-1}$, gave in turn a higher yield of $20.92 \mathrm{t} \mathrm{ha}^{-1}$ whereas with $75 \% \mathrm{RDF} \mathrm{ha}^{-1}\left(19.85 \mathrm{tha}^{-1}\right), 50 \% \mathrm{RDF} \mathrm{ha}^{-1}\left(18.57 \mathrm{tha}^{-1}\right)$ and with $0 \% \mathrm{RDF}^{-1}$ $\left(10.10 \mathrm{t} \mathrm{ha}^{-1}\right)$ acheived with per day return of Rs. 628.52, Rs. 584.11 and Rs. 251.11, respectively.

But in case of liming @ $200 \mathrm{~kg} \mathrm{ha}^{-1}$ pooled values of both the yields (Table-4) of $\mathrm{L}_{200} \mathrm{M}_{4} \mathrm{R}_{50}$ and $\mathrm{L}_{200} \mathrm{M}_{0} \mathrm{R}_{50}$ were found higher than higher doses of nitrogen which is also higher in the final year than the rest two years w.r.t 100\% RDF where the dosage of Lime and Mo are constant which might be due to year after year continuous application of lime leading to overliming creating deficiency of cations and sudden precipitations of available sulphate ions disturbing the required $\mathrm{N}: \mathrm{S}$ ratio of 15-16:1. Pasricha and Sarkar, (2012) and Tandon (1995) also reported similar findings.

\section{CONCLUSION}

By virtue of its resilience in rainfed condition, pigeon pea will play a greater role in our agriculture. The combination of $150 \mathrm{~kg} \mathrm{ha}^{-1}$ of lime and seed treatment with molybdenum @ $4 \mathrm{~g} \mathrm{~kg}^{-1}$ of seed treatment and 100\% of recommended dose showed higher B: $\mathrm{C}$ ratio but it was achieved with intensive use of chemical fertilizer deteriorating the soil health and increasing the production cost. Further investigation reflect that by the use of $75 \% \mathrm{RDF} \mathrm{ha}^{-1}$ per day return was only Rs. 60.39 less compare to $100 \% \mathrm{RDF} \mathrm{ha}^{-1}$ with saving the cost of $25 \% \mathrm{RDF} \mathrm{ha}^{-1}$. So, from overall and particularly economic point of view, we have come to conclusion that the treatment $\mathrm{L}_{150} \mathrm{M}_{4} \mathrm{R}_{75}\left(150 \mathrm{~kg} \mathrm{ha}^{-1}\right.$ lime with $4 \mathrm{~g} \mathrm{~kg}^{-1}$ of molybdenum seed treatment and $75 \%$ of recommended dose) can be suggested for nutrient management practice of pigeonpea under rainfed conditions in Alfisols.

\section{REFERENCES}

Ahlawat, I.P.S., Gangaiah, B. and Singh, I. P. 2005. Pigeonpea (Cajanus cajan) research in India-an overview. Indian Journal of Agricultural Sciences, 75 (6): 309-20

Bhuiyan, M.A.H., Khanam, D. and Ali, M.Y. 1999. Chickpea root nodulation and yield as affected by micronutrient application and rhizobium inoculation. International Chickpea and Pigeonpea Newsletter, 6: 28-29

Das, D. K. 1996. Introductory Soil Science. $3^{\text {rd }}$ edn. Kalyani Publishers, Ludhiana, India

De, B. and Bandyopadhyay, S. 2013. Influence of soil conservation techniques on growth and yield of maize (zea mays 1.) in Terai region of west Bengal. SAARC Journal of Agriculture, 11(1): 133-147

De, B., Sinha, A. C. and Patra, P.S. 2009. Effect of organic and inorganic sources of nutrients on rapeseed (Brassica campestris L.) under terai region. Journal of Crop Weed, 5(1): 281-284 
Gopalan, C., Rama Sastri, B.V. and Balasubramanian, S.C. 1971. Nutritive value of Indian Foods. National Institute of Nutrition (NIN), Hyderabad, India.p-204

Kumar Rao, J.V.D.K. 1990. Pigeon pea: nitrogen fixation. Pp: 233-256 (in) The Pigeon pea (Eds.; Y L Nene, S D Hall and V K Sheila), CAB international, Wallingford, UK

Kumar Rao, J.V.D.K. and Dart, P.J. 1987. Nodulation, Nitrogen fixation and N2 uptake in pigeon pea (Cajanus cajan L. Millsp.) of different maturity groups. Plant \& Soil, 99: 255-266

Pasricha, N.S. and Sarkar, A.K. 2012. Secondary nutrients-Fundamentals of Soil Science, Indian Society of Soil Science, New Delhi.pP-457

Prasad, M., Pillai, A., Faber, G., Field, S. and Dowling, T. 1998. Molybdenum response of pigeonpea on Ferruginous Latosols in Fiji. International Chickpea and Pigeonpea Newsletter, 5: 55-56

Puste, A.M. and Jana, P.K. 1995. Effect of phosphorus and zinc on the yield attributes and yield of pigeon pea varieties grown during winter season. Madras Agricultural Journal, 82: 348-351

Ramakrishna, A., Wani, S.P., Rao, ChSrinivasa. and Srinivas Reddy, U. 2005. Effect of Improved Crop ProductionTechnology on Pigeon pea Yield inResource Poor Rainfed Areas, An Open Access Journal published by ICRISAT Vol. 1(1)

Reddy, M, Padmaja, B., Malathi S. and Jalapathi Rao, L. 2007. Effects of micronutrients on growth and yield of pigeonpea. Journal of SAT Agricultural Research, 5(1)

Sharma, A., Gupta, R. and Kumar, A. 2007. Production potential of rapeseed (Brassica juncea) under varying sowing methods and at different sulphur and nitrogen levels. Plant-Archives, 7: 893-96

Sharma, A., Nakul, H.T., Jelgeri, B. R. and Surwenshi, A. 2010. Effect of micronutrients on growth, yield and yield components in Pigeon pea (Cajanus cajan L. Millsp.). Research Journal of Agricultural Sciences, 1(2): 142-144

Tandon, H.L.S. 1995. Sulphur fertilizers for Indian Agriculture-A Guidebook, Fertiliser Development and Consultation Organisation, New Delhi

Velayutham, V., Kalpana, R. and Muthiah, A.R. 2003. Studies on micronutrient fertilization in urdbean. Page 177 in Proceedings of the National Symposium on Pulses for Crop Diversification and Natural Resource Management, 20-22 Dec 2003, IIPR, Kanpur, India. Kanpur, India: Indian Institute of Pulses Research

Verma, E. B., Lallu, and Yadav, R. S. 2004. Effect of boron and zinc application on growth and yield of pigeon pea. Indian Journal of Pulse Research, 17 (2): 149-151

Yadav, R.P., Sharma, R.K. and Shrivastava, U.K. 1997. Fertility management in pigeon pea based intercropping system under rain fed conditions. Indian Journal of Agronomy, 42:.46-49 
Table 1. Monthly mean meteorological data pertaining to the period of experiment

\begin{tabular}{|c|c|c|c|c|c|c|c|c|c|c|c|c|c|c|c|c|c|c|c|c|}
\hline \multirow[t]{3}{*}{ Month } & \multicolumn{8}{|c|}{ Temperature $\left({ }^{0} \mathrm{C}\right)$} & \multirow{2}{*}{\multicolumn{4}{|c|}{$\frac{\text { Relative humidity (\%) }}{\text { Average }}$}} & \multirow{2}{*}{\multicolumn{4}{|c|}{ Total rainfall $(\mathrm{mm})$}} & \multirow{2}{*}{\multicolumn{4}{|c|}{$\begin{array}{c}\text { Sunshine hours } \\
\text { day }^{-1}\end{array}$}} \\
\hline & \multicolumn{4}{|c|}{ Max. } & \multicolumn{4}{|c|}{ Min. } & & & & & & & & & & & & \\
\hline & 葛 & $\overline{\bar{\sigma}}$ & 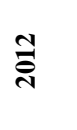 & $\stackrel{m}{\vec{N}}$ & 葛 & $\overline{\bar{\gamma}}$ & 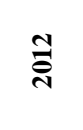 & $\stackrel{m}{\stackrel{\sim}{二}}$ & 莡 & $\overline{\bar{\lambda}}$ & $\stackrel{\widetilde{I}}{\overline{\mathrm{d}}}$ & 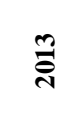 & 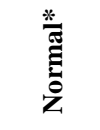 & $\overline{\bar{d}}$ & 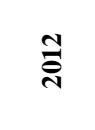 & $\stackrel{m}{\vec{\pi}}$ & 蕞 & 옥 & $\overline{\bar{d}}$ & 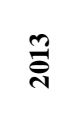 \\
\hline $\mathbf{J a n}^{+}$ & 25.34 & 21.97 & 20.97 & 25.34 & 10.18 & 9.55 & 10.84 & 10.18 & 92.50 & 92.50 & 91.97 & 58.80 & 9.76 & 0.00 & 1.40 & 0.00 & 5.75 & 5.67 & 5.89 & 5.77 \\
\hline Feb & 21.38 & 28.22 & 27.19 & 21.38 & 9.98 & 14.09 & 13.45 & 9.98 & 90.72 & 91.20 & 91.44 & 47.00 & 17.65 & 0.60 & 8.60 & 10.31 & 7.26 & 7.33 & 6.92 & 7.17 \\
\hline Mar & 29.82 & 31.12 & 31.11 & 30.60 & 16.66 & 18.72 & 20.10 & 20.13 & 88.96 & 85.75 & 74.12 & 72.85 & 37.80 & 2.40 & 1.50 & 2.50 & 6.96 & 6.25 & 4.10 & 5.77 \\
\hline Apr & 30.01 & 30.68 & 31.13 & 31.30 & 20.01 & 21.60 & 20.24 & 22.05 & 89.19 & 90.50 & 75.53 & 75.32 & 269.75 & 0.00 & 97.70 & 101.32 & 5.93 & 4.98 & 4.50 & 5.14 \\
\hline May $^{+}$ & 31.43 & 30.40 & 31.56 & 31.43 & 22.65 & 22.10 & 23.26 & 22.65 & 89.49 & 70.80 & 78.76 & 70.00 & 327.36 & 193.20 & 269.40 & 691.90 & 6.13 & 4.86 & 5.00 & 5.33 \\
\hline June $^{+}$ & 34.65 & 29.93 & 33.06 & 34.65 & 25.10 & 23.23 & 25.18 & 25.10 & 72.53 & 75.50 & 65.64 & 76.00 & 625.80 & 360.20 & 705.00 & 413.90 & 4.26 & 2.93 & 3.60 & 3.60 \\
\hline July $^{+}$ & 32.90 & 31.75 & 31.41 & 32.90 & 25.22 & 25.15 & 25.60 & 25.22 & 82.29 & 81.25 & 71.43 & 77.00 & 516.30 & 259.90 & 726.20 & 241.90 & 4.00 & 4.15 & 6.80 & 4.98 \\
\hline Aug $^{+}$ & 32.03 & 32.75 & 32.75 & 32.03 & 24.70 & 25.95 & 25.55 & 24.70 & 71.56 & 71.50 & 84.81 & 77.75 & 426.14 & 433.80 & 440.10 & 176.00 & 4.79 & 5.45 & 5.95 & 5.40 \\
\hline Sept $^{+}$ & 32.63 & 30.88 & 32.93 & 32.63 & 24.63 & 24.60 & 25.43 & 24.63 & 82.41 & 92.25 & 83.96 & 77.25 & 333.05 & 226.60 & 446.60 & 261.40 & 4.99 & 3.40 & 5.25 & 4.55 \\
\hline Oet $^{+}$ & 30.76 & 30.85 & 34.17 & 30.76 & 22.04 & 22.35 & 23.36 & 22.04 & 91.25 & 91.50 & 72.09 & 77.00 & 235.13 & 129.50 & 12.90 & 115.10 & 6.77 & 7.03 & 5.56 & 6.45 \\
\hline Nov $^{+}$ & 29.43 & 26.79 & 26.88 & 29.43 & 15.50 & 12.87 & 10.75 & 15.50 & 71.26 & 70.67 & 71.25 & 72.50 & 19.80 & 8.00 & 5.10 & 0.00 & 8.20 & 7.86 & 7.91 & 7.99 \\
\hline $\operatorname{Dec}^{+}$ & 26.48 & 23.81 & 21.64 & 26.48 & 11.45 & 11.59 & 9.55 & 11.45 & 92.30 & 93.56 & 90.22 & 62.25 & 15.00 & 03.10 & 0.00 & 2.40 & 7.11 & 7.20 & 6.92 & 7.08 \\
\hline
\end{tabular}

+ Months denoting experimental period

*Average meteorological data for the last 35 years 
Table 2. ANOVA results for effects of liming, molybdenum seed treatment and levels of recommended dose on measured variables from pigeonpea

\begin{tabular}{|c|c|c|c|c|c|c|c|}
\hline Source & Plant height & $\begin{array}{l}\text { Primary } \\
\text { branches }\end{array}$ & $\begin{array}{l}\text { Pod per } \\
\text { plant }\end{array}$ & $\begin{array}{l}\text { Number of seed } \\
\text { per pod }\end{array}$ & $\begin{array}{l}100 \text { seed } \\
\text { weight }\end{array}$ & Grain yield & Stick yield \\
\hline Liming (L) & ns & ns & $*$ & ns & ns & ns & ns \\
\hline Molybdenum seed treatment (M) & $* * *$ & ns & $* * *$ & ns & ns & $* * *$ & $* * *$ \\
\hline Levels of recommended dose (R) & $* * *$ & $* *$ & $* * *$ & ns & ns & $* * *$ & $* * *$ \\
\hline $\mathrm{L} \times \mathrm{M}$ & ns & ns & ns & ns & ns & $* *$ & $* *$ \\
\hline $\mathrm{L} \times \mathrm{R}$ & ns & ns & $* * *$ & ns & ns & $*$ & ns \\
\hline$M \times R$ & $*$ & ns & $* * *$ & ns & ns & ns & ns \\
\hline $\mathrm{L} \times \mathrm{M} \times \mathrm{R}$ & * & ns & $* * *$ & ns & $\mathrm{ns}$ & $\mathrm{ns}$ & Ns \\
\hline
\end{tabular}

$\mathrm{ns}, *, * *, * * *$, non-significant or significant at $p \leq 0.05$ or $p \leq 0.01$, ANOVA 
Table 3. Effect of liming, molybdenum seed treatment and different levels of recommended doses on growth, flowering, yield and yield attributing characters of pigeon pea (Pooled over 3 years)

\begin{tabular}{|c|c|c|c|c|c|c|c|c|c|c|}
\hline \multirow[b]{2}{*}{ Treatments } & \multicolumn{4}{|c|}{ Growth and flowering characters } & \multicolumn{3}{|c|}{ Yield attributing characters } & \multicolumn{3}{|c|}{ Yield characters } \\
\hline & $\begin{array}{l}\text { Plant } \\
\text { Height } \\
(\mathrm{cm})\end{array}$ & $\begin{array}{l}\text { Primary } \\
\text { branches }\end{array}$ & $\begin{array}{l}\text { Days to } 1^{\text {st }} \\
\text { flowering } \\
\text { (days) }\end{array}$ & $\begin{array}{l}\text { Days to } 50 \% \\
\text { flowering } \\
\text { (days) }\end{array}$ & $\begin{array}{c}\text { No. of } \\
\text { pods/plant }\end{array}$ & $\begin{array}{c}\text { No. of } \\
\text { seed/pod }\end{array}$ & $\begin{array}{c}100 \\
\text { seed } \\
\text { weight } \\
(\mathrm{g})\end{array}$ & $\begin{array}{c}\text { Grain } \\
\text { Yield (kg } \\
\left.\mathrm{h}^{-1} \mathrm{a}\right)\end{array}$ & $\begin{array}{c}\text { Stick } \\
\text { yield (kg } \\
\left.\text { ha }^{-1}\right)\end{array}$ & $\begin{array}{c}\text { Harvest } \\
\text { Index }\end{array}$ \\
\hline \multicolumn{11}{|l|}{ Liming $(L)$} \\
\hline $\mathrm{L}_{150}$ & 125.71 & 8.86 & 65 & 83 & 113.07 & 3.54 & 7.82 & 1504.40 & 4008.40 & 27.36 \\
\hline $\mathrm{L}_{200}$ & 124.86 & 9.22 & 68 & 84 & 106.05 & 3.50 & 7.85 & 1519.50 & 3910.20 & 27.86 \\
\hline S.E. \pm & 0.96 & 0.14 & 0.94 & 0.94 & 0.96 & 0.03 & 0.10 & 17.97 & 53.25 & \\
\hline C.D $(p=0.05)$ & N.S & N.S & N.S & N.S & 5.86 & N.S & N.S & N.S & N.S & \\
\hline \multicolumn{11}{|c|}{ Molybdenum $(M)$ seed treated } \\
\hline $\mathrm{M}_{4}$ & 131.86 & 9.41 & 66 & 84 & 116.02 & 3.58 & 8.10 & 1594.20 & 4167.60 & 27.73 \\
\hline $\mathrm{M}_{0}$ & 119.29 & 8.68 & 64 & 83 & 103.10 & 3.46 & 7.57 & 1429.70 & 3751.10 & 27.50 \\
\hline S.E. \pm & 0.47 & 0.23 & 0.50 & 0.50 & 0.47 & 0.22 & 0.27 & 5.75 & 20.32 & \\
\hline C.D. $(p=0.05)$ & 1.83 & N.S & N.S & N.S & 1.83 & N.S & N.S & 22.58 & 79.79 & \\
\hline \multicolumn{11}{|c|}{ Levels of Recommended Dose $(R)$} \\
\hline $\mathrm{R}_{0}$ & 104.40 & 6.52 & 67 & 87 & 86.42 & 3.08 & 6.77 & 964.60 & 2890.90 & 24.96 \\
\hline $\mathrm{R}_{50}$ & 122.50 & 8.92 & 66 & 83 & 121.42 & 3.58 & 7.98 & 1539.00 & 4244.70 & 26.63 \\
\hline $\mathrm{R}_{75}$ & 134.60 & 10.72 & 66 & 82 & 118.73 & 3.67 & 7.89 & 1739.30 & 3886.00 & 31.53 \\
\hline $\mathrm{R}_{100}$ & 139.65 & 10.01 & 66 & 83 & 111.67 & 3.75 & 8.69 & 1804.90 & 4815.60 & 27.33 \\
\hline S.E. \pm & 2.08 & 0.80 & 2.09 & 2.08 & 2.08 & 0.47 & 0.56 & 60.77 & 210.95 & \\
\hline C.D. $(p=0.05)$ & 6.05 & 2.34 & N.S & N.S & 6.06 & N.S & N.S & 177.37 & 615.71 & \\
\hline
\end{tabular}

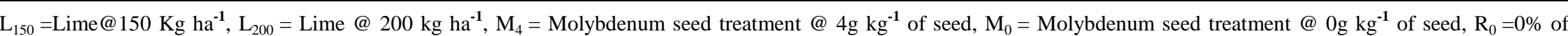
$\mathrm{RDF} / \mathrm{ha}, \mathrm{R}_{50}=50 \%$ of RDF/ha, $\mathrm{R}_{75}=75 \%$ of RDF/ha and $\mathrm{R}_{100}=100 \%$ of RDF/ha (RDF=Recommended dose @ 20:60:40 of NPK). 
Table 4. Effect of liming, molybdenum seed treatment and different levels of recommended doses on economics of pigeon pea (Pooled over 3 years)

\begin{tabular}{|c|c|c|c|c|c|c|c|c|c|c|}
\hline \multicolumn{2}{|c|}{ Treatment } & \multirow{2}{*}{$\begin{array}{c}\begin{array}{c}\text { Grain } \\
\text { yield (t ha } \\
\mathbf{1})\end{array} \\
9.96\end{array}$} & \multirow{2}{*}{$\begin{array}{c}\begin{array}{c}\text { Stalk yield } \\
\left(\mathbf{t ~ h a}^{-1}\right)\end{array} \\
29.05\end{array}$} & \multirow{2}{*}{$\begin{array}{c}\begin{array}{c}\text { Value of Grain } \\
\text { yield (Rs.) }\end{array} \\
43363.85\end{array}$} & \multirow{2}{*}{$\begin{array}{c}\begin{array}{c}\text { Value of Stalk } \\
\text { yield (Rs.) }\end{array} \\
5811.53\end{array}$} & \multirow{2}{*}{$\begin{array}{c}\begin{array}{c}\text { Gross Return } \\
\text { (Rs.) }\end{array} \\
49175.37\end{array}$} & \multirow{2}{*}{$\begin{array}{c}\begin{array}{c}\text { Total Cost } \\
\text { (COST C)( Rs.) }\end{array} \\
18720.00\end{array}$} & \multirow{2}{*}{$\begin{array}{c}\begin{array}{c}\text { NET RETURN } \\
\text { (Rs.) }\end{array} \\
30455.37\end{array}$} & \multirow{2}{*}{$\begin{array}{c}\begin{array}{c}\text { Per Day } \\
\text { Return } \\
\text { (Rs.) }\end{array} \\
253.79\end{array}$} & \multirow{2}{*}{$\begin{array}{r}\text { B:C } \\
\text { Ratio } \\
1.63\end{array}$} \\
\hline & $\mathrm{M}_{4} \mathrm{R}_{0}$ & & & & & & & & & \\
\hline \multirow[t]{8}{*}{$\mathrm{L}_{150}$} & $\mathrm{M}_{4} \mathrm{R}_{50}$ & 14.08 & 39.50 & 61248.00 & 7901.86 & 69149.86 & 19470.00 & 49679.86 & 414.00 & 2.55 \\
\hline & $\mathrm{M}_{4} \mathrm{R}_{75}$ & 19.85 & 45.11 & 86369.25 & 9022.84 & 95392.09 & 19970.00 & 75422.09 & 628.52 & 3.78 \\
\hline & $\mathrm{M}_{4} \mathrm{R}_{100}$ & 20.92 & 59.25 & 91038.54 & 11851.16 & 102889.70 & 20220.00 & 82669.70 & 688.91 & 4.09 \\
\hline & $\mathrm{M}_{0} \mathrm{R}_{0}$ & 9.88 & 28.89 & 43006.28 & 5778.31 & 48784.58 & 18000.00 & 30784.58 & 256.54 & 1.71 \\
\hline & $\mathrm{M}_{0} \mathrm{R}_{50}$ & 13.21 & 37.85 & 57477.86 & 7570.78 & 65048.64 & 18750.00 & 46298.64 & 385.82 & 2.47 \\
\hline & $\mathrm{M}_{0} \mathrm{R}_{75}$ & 16.00 & 35.13 & 69633.93 & 7027.83 & 76661.76 & 19200.00 & 57461.76 & 478.85 & 2.99 \\
\hline & $\mathbf{M}_{0} \mathbf{R}_{100}$ & 16.41 & 45.85 & 71401.34 & 9170.88 & 80572.21 & 19500.00 & 61072.21 & 508.94 & 3.13 \\
\hline & $\mathrm{M}_{4} \mathrm{R}_{0}$ & 10.10 & 29.58 & 43935.00 & 5917.84 & 49852.84 & 19720.00 & 30132.84 & 251.11 & 1.53 \\
\hline \multirow[t]{7}{*}{$\mathrm{L}_{200}$} & $\mathrm{M}_{4} \mathrm{R}_{50}$ & 18.57 & 48.86 & 80789.51 & 9773.74 & 90563.25 & 20470.00 & 70093.25 & 584.11 & 3.42 \\
\hline & $\mathrm{M}_{4} \mathrm{R}_{75}$ & 16.56 & 38.15 & 72055.58 & 7630.08 & 79685.66 & 20920.00 & 58765.66 & 489.71 & 2.81 \\
\hline & $\mathrm{M}_{4} \mathrm{R}_{100}$ & 17.47 & 43.85 & 75994.50 & 8771.89 & 84766.39 & 21280.00 & 63486.39 & 529.05 & 2.98 \\
\hline & $\mathrm{M}_{0} \mathrm{R}_{0}$ & 8.63 & 28.09 & 37540.50 & 5619.89 & 43160.39 & 19000.00 & 24160.39 & 201.34 & 1.27 \\
\hline & $\mathrm{M}_{0} \mathrm{R}_{50}$ & 15.69 & 43.55 & 68270.64 & 8711.22 & 76981.86 & 19750.00 & 57231.86 & 476.93 & 2.90 \\
\hline & $\mathrm{M}_{0} \mathrm{R}_{75}$ & 17.14 & 37.03 & 74571.62 & 7407.30 & 81978.91 & 20200.00 & 61778.91 & 514.82 & 3.06 \\
\hline & $\mathbf{M}_{0} \mathbf{R}_{100}$ & 17.38 & 43.65 & 75623.01 & 8731.17 & 84354.18 & 20560.00 & 63794.18 & 531.62 & 3.10 \\
\hline
\end{tabular}

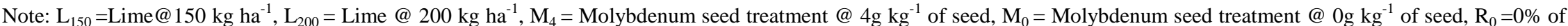
$\mathrm{RDF} / \mathrm{ha}, \mathrm{R}_{50}=50 \%$ of RDF/ha, $\mathrm{R}_{75}=75 \%$ of RDF/ha and $\mathrm{R}_{100}=100 \%$ of RDF/ha (RDF=Recommended dose @ 20:60:40 of NPK). MSP Recommended by CACP=Rs. 4350 $\mathrm{t}^{-1}$, Value of Stalk yield=Rs. $200 \mathrm{t}^{-1}$, Cost of Lime @ Rs. $12 \mathrm{~kg}^{-1}$, Molybdenum @ Rs. $12 \mathrm{~g}^{-1}$, Urea @ Rs. $10 \mathrm{~kg}^{-1}, \mathrm{SSP} @ \mathrm{Rs} .7 \mathrm{~kg}{ }^{-1}, \mathrm{MOP} @ \mathrm{Rs} .15 \mathrm{~kg}^{-1}$, \#All the above prices are considered to be average of 3 years. 

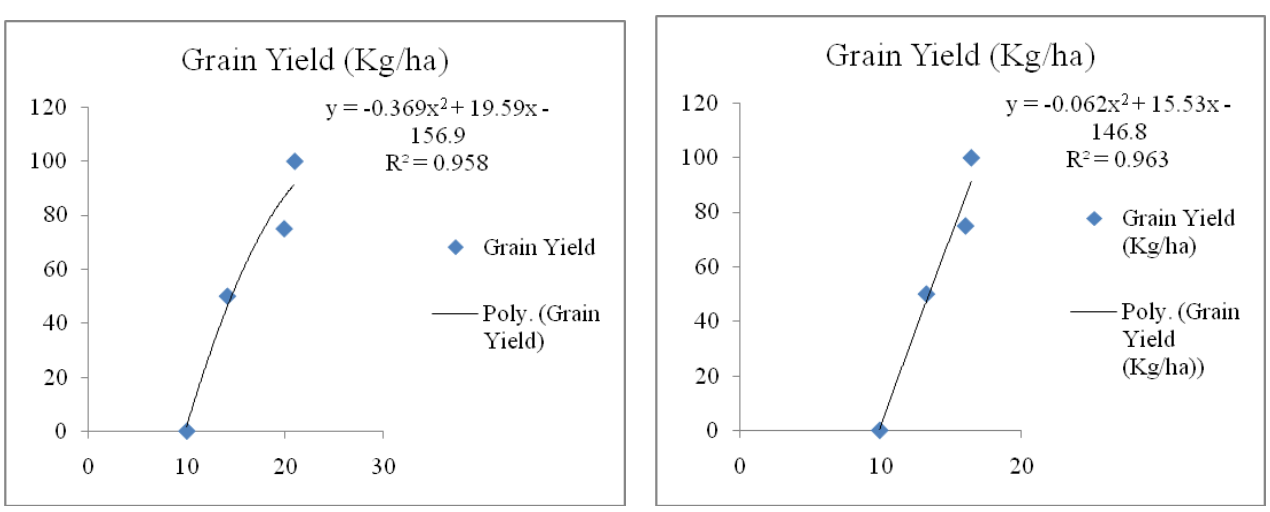

Figure1: Curve fitting of grain yield under Liming @ $150 \mathrm{~kg} \mathrm{ha}^{-1}$ with Molybdenum a) Treated b) Non-treated
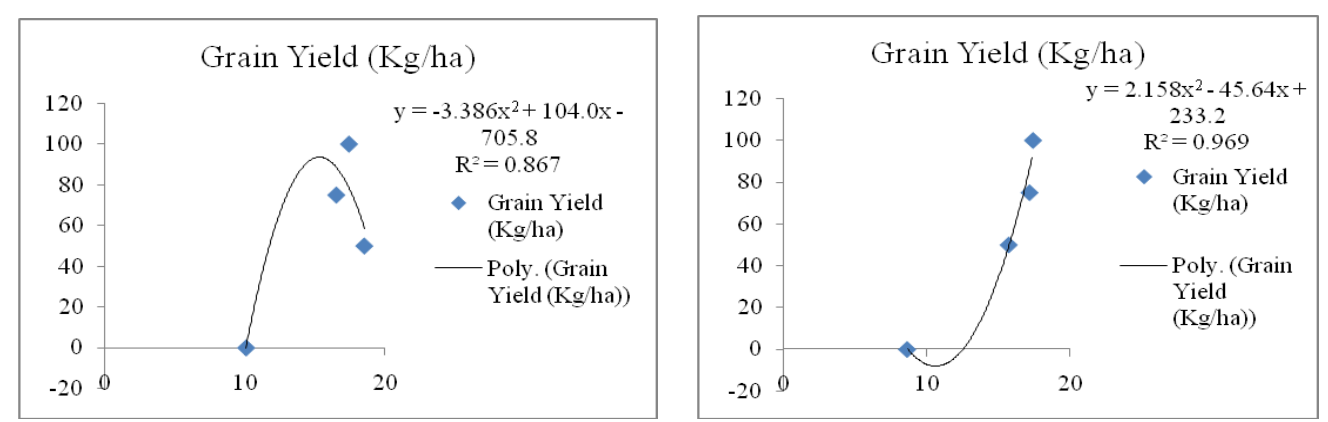

Figure 2. Curve fitting of grain yield under Liming @ $200 \mathrm{~kg} \mathrm{ha}^{-1}$ with Molybdenum a) Treated b) Non-treated 